\title{
Effect of the inclusion of lysine and methionine on the nutritional performance and ingestive behavior of lambs
}

\author{
Efeito da inclusão de lisina e metionina protegidas sobre o \\ desempenho nutricional e comportamento ingestivo de borregas
}

\author{
Carolina Moreira Araújo ${ }^{1 *}$; Gilberto de Lima Macedo Junior ${ }^{2}$; Karla Alves \\ Oliveira $^{1}$; Laura Ferrari Monteiro Varanis ${ }^{1}$; Tamires Soares de Assis ${ }^{3}$; Marco Túlio \\ Santos Siqueira ${ }^{4}$
}

\begin{abstract}
Lysine and methionine are the most limiting amino acids for ruminants; their inclusion in the free form is not effective, since they are quickly degraded by ruminal microorganisms, making the fulfillment of the requirements of metabolizable protein difficult. The objective of this study was to evaluate the effects of including different levels of lysine and methionine, protected from ruminal degradation, in the diet of lambs; more specifically, their effects on intake, digestibility, nitrogen balance and ingestive behavior. The experiment was conducted at the Experimental Farm Capim Branco, Federal University of Uberlândia, from September to October 2016. Five ${ }^{1 / 2}$ Dorper $x{ }^{1 / 2}$ Santa Inês lambs, at approximately eight months of age and an average weight of $50 \mathrm{~kg}$, were distributed in a $5 \times 5$ Latin square design, with five treatments and five replicates. The treatments consisted of different levels $(0 \mathrm{~g}, 8 \mathrm{~g}, 16 \mathrm{~g}, 24 \mathrm{~g}$ and $32 \mathrm{~g}$ ) of lysine and methionine added to the diet, protected from ruminal degradation (MicroPEARLS LM $\left.{ }^{\circledR}\right)$. The feed was composed of corn silage and concentrate (30V: $\left.70 \mathrm{C}\right)$, offered twice daily at $08 \mathrm{~h} 00$ and $16 \mathrm{~h} 00$. The experiment lasted 75 days and was divided into five phases. Each phase lasted 15 days, with 10 days for adaptation of the animals and five days of data collection. The animals were kept in individual metabolic cages, with a feeder, drinker and salt shaker. A digestibility assay was performed to determine the consumption and apparent digestibility coefficients of dry matter (DM), crude protein (CP), neutral detergent fiber and acid (NDF/NDA). Urine volume and density, stool weight and fecal score, nitrogen balance and ingestive behavior were recorded. In relation to metabolic and body weight, DM intake $\left(\mathrm{kg} \mathrm{day}^{-1}\right)$ presented a positive linear response with the inclusion of amino acids, as well as the CP intake, NDF intake, ingested nitrogen and nitrogen balance, which were positive in all treatments. There was no difference $(\mathrm{P}<0.05)$ in the digestibility coefficients of DM, CP and $\mathrm{NDF}$. Water consumption was high in all treatments, but did not differ by treatment $(\mathrm{P}>0.05)$. Ingestive behavior was not influenced ( $\mathrm{P}>0.05$ ). The inclusion of up to $32 \mathrm{~g}$ of protected lysine and methionine increases DM and nutrient intake, without negatively affecting digestibility. The high $\mathrm{CP}$ intake induced an increase in the urinary nitrogen excretion, and consequently, an increase in the energy expenditure.
\end{abstract}

Key words: Amino acids. Digestibility. Nitrogen. Ovis aries. Protein.

\footnotetext{
' Mestres em Produção Animal, Nutrição de Ruminantes, Programa de Pós-Graduação em Ciências Veterinárias, Universidade Federal de Uberlândia, UFU, Uberlândia, MG, Brasil. E-mail: carolina.am@hotmail.com; karla.alves.oliveira@hotmail.com; laura_ferrari@gmail.com

2 Prof. Dr., UFU, Faculdade de Medicina Veterinária, Programa de Pós-Graduação em Ciências Veterinárias, Uberlândia, MG, Brasil. E-mail: gilbertomacedojr@gmail.com

3 Discente, Curso de Mestrado do Programa de Pós-Graduação em Ciências Veterinárias, UFU, Uberlândia, MG, Brasil. E-mail: tamires.manejo@gmail.com

4 Discente, Curso de Graduação em Zootecnia, UFU, Uberlândia, MG, Brasil. E-mail: marcotulio.s.siqueira@gmail.com

* Author for correspondence
} 


\section{Resumo}

Lisina e metionina são os aminoácidos mais limitantes para ruminantes. Sua inclusão na forma livre não é eficaz, visto que os microrganismos ruminais os degradam rapidamente, dificultando o atendimento das exigências de proteína metabolizável. Objetivou-se avaliar a inclusão de diferentes teores de lisina e metionina protegidos da degradação ruminal na ração de borregas, sobre o consumo, digestibilidade, balanço de nitrogênio e comportamento ingestivo. O experimento foi realizado na Fazenda Experimental Capim Branco, da Universidade Federal de Uberlândia, no período de setembro à outubro de 2016. Foram utilizadas cinco borregas ${ }^{1 / 2}$ Dorper $x{ }^{1 / 2}$ Santa Inês, com aproximadamente oito meses de idade e peso médio de $50 \mathrm{~kg}$, distribuídas em esquema quadrado latino $5 \times 5$, sendo cinco tratamentos e cinco repetições. Os tratamentos consistiram na inclusão de diferentes teores de lisina e metionina protegidos da degradação ruminal (MicroPEARLS LM $^{\circledR}$ ) na ração, sendo: $0 \mathrm{~g}, 8 \mathrm{~g}, 16 \mathrm{~g}, 24 \mathrm{~g}$ e $32 \mathrm{~g}$. A ração era composta por silagem de milho e concentrado, na proporção $30 \mathrm{~V}: 70 \mathrm{C}$, sendo ofertadas duas vezes ao dia ( 8 e 16 horas). O experimento teve duração de 75 dias, sendo divido em cinco fases. Cada fase teve duração de quinze dias, sendo dez dias de adaptação dos animais e cinco dias de coleta de dados. Os animais foram mantidos em gaiolas metabólicas individuais, dispostas de comedouro, bebedouros e saleiro. Foi realizado um ensaio de digestibilidade para determinar o consumo e os coeficientes de digestibilidade aparente da matéria seca (MS), proteína bruta (PB), fibra em detergente neutro e ácido (FDN/FDA). Foram obtidos o volume e densidade de urina, peso das fezes e escore fecal, balanço de nitrogênio e estudo de comportamento ingestivo. Os consumos de MS $\left(\mathrm{kg} \mathrm{dia}^{-1}\right)$, e em relação ao peso metabólico e corporal, apresentaram equações lineares positivas à inclusão dos aminoácidos, assim como os consumos de PB, FDN, nitrogênio ingerido e balanço de nitrogênio, que foram positivos em todos os tratamentos. Não houve diferença $(\mathrm{P}<0,05)$ para os coeficientes de digestibilidade da MS, $\mathrm{PB}$ e FDN. O consumo de água foi elevado em todos os tratamentos e não diferiram entre si $(\mathrm{P}>0,05)$. $\mathrm{O}$ comportamento ingestivo não foi influenciado $(\mathrm{P}>0,05)$.

Palavras-chave: Aminoácidos. Digestibilidade. Nitrogênio. Ovis Aries. Proteína.

\section{Introduction}

Metabolizable protein systems have stimulated and permitted advances in the knowledge of the amino acid requirements of ruminants and the balancing of the essential amino acid profile (EAA) of metabolizable protein (SANTOS et al., 2017). The EAA profile of the protein that reaches the gut is as important as the quantity of this protein in terms of maximizing animal performance. When the metabolizable protein has an adequate profile of essential amino acids, the crude protein content of the feed can be reduced, together with the excretion of urea and other nitrogen compounds, optimizing the use of the metabolizable protein and maximizing animal performance (SANTOS, 2006).

Foods commonly used to feed ruminants meet the requirements of rumen degradable protein, but present an undegradable protein deficit; therefore, supplementation is necessary through the inclusion of amino acids protected from ruminal degradation. This strategy allows the amino acids to reach the small intestine and, together with the microbial protein and endogenous protein, meet ruminants' metabolizable protein requirements to maximize productive performance (VALADARES FILHO, 1997).

Supplementation with essential amino acids can reduce the excretion of nitrogen into the environment and, depending on the cost of the diet, can be more economical (ARRIOLA APELO et al., 2014). Nitrogen excretion has a high energy cost for the animal, since the conversion of ammonia into urea is performed in the liver; its reduction allows for a redirection of this energy to other functions, such as growth and maintenance. With this, the consumption and digestibility of the food can be high, in order to meet nutritional requirements, leading to an increase in the performance of the animals. 
Consumption, digestibility and nutrient metabolism directly reflect on the productive response of the animals. Consumption is responsible for 60 to $90 \%$ of the variation observed in the intake of digestible energy between animals and diets, whereas digestibility represents between 10 and $40 \%$ of this difference (REID, 1961). The evaluation of ingestive behavior allows for the determination of the quality of the diet and for an adjustment in food management.

In view of the above, the objective of this study was to evaluate the effects of including different levels of amino acids (lysine and methionine) protected from ruminal degradation in sheep rations on intake, digestibility, nitrogen balance and ingestive behavior.

\section{Material and Methods}

The experiment was conducted at the Experimental Capim Branco Farm, belonging to the Faculty of Veterinary Medicine of the Federal University of Uberlândia (UFU), in Uberlândia, MG, from September to October 2016. The experiment was submitted to the institutional ethics committee for the use of animals (CEUA) and obtained approval under protocol $\mathrm{n}^{\circ} 128 / 16$.

Five $1 / 2$ Dorper $x 1 / 2$ Santa Inês lambs were used, at approximately eight months of age and an average weight of $50 \mathrm{~kg}$. The ewes were vermifugated before the start of the experimental period with oral monepantel. The animals were housed in individual metabolic cages (INCT standard), with ripened wood flooring, a feeder, drinker and salt shaker. The cages were kept in cement-floored sheds and covered by clay tiles, with lateral ventilation and protection from direct solar radiation.

The treatments were randomly selected and consisted of the inclusion of different levels of MicroPEARLS LM ${ }^{\circledR}$ product $(0 \mathrm{~g}, 8 \mathrm{~g}, 16 \mathrm{~g}, 24 \mathrm{~g}$ and $32 \mathrm{~g}$ ); this amino acid supplement (lysine and methionine) is encapsulated (Table 1). The ration was balanced according to the NRC (2007) for gains of $250 \mathrm{~g} \mathrm{day}^{-1}$; it was composed of corn silage and concentrate in the $70 \mathrm{C}: 30 \mathrm{~V}$ ratio (Table 1). The experiment lasted 75 days and was divided into five phases. Each phase had a duration of 15 days, with 10 days for the adaptation of the animals and five days for the collection of samples.

Table 1. Chemical and bromatological composition (\%) of concentrate and corn silage.

\begin{tabular}{ccccc}
\hline Ingredient & Concentrate & Corn silage & MicroPEARLS LM $^{\mathbb{B}^{*}}$ & Total ration \\
\hline Crushed corn & $60.5^{* *}$ & - & - & - \\
Soybean meal & $36.0^{* *}$ & - & - & - \\
Urea & $1.0^{* *}$ & - & - & - \\
Mineral salt & $2.5^{* *}$ & - & - & - \\
DM & $90.2^{* *}$ & $32.2^{* *}$ & $99.0^{*}$ & $72,8^{* *}$ \\
CP & $24.9^{* *}$ & $6.3^{* *}$ & $43.75^{*}$ & $19.36^{* *}$ \\
NDF & $24.8^{* *}$ & $54.6^{* *}$ & - & $33.74^{* *}$ \\
NDA & $7.0^{* *}$ & $32.6^{* *}$ & - & $14.68^{* *}$ \\
EE & - & - & $48.65^{*}$ & - \\
\hline
\end{tabular}

* Information provided by the manufacturer; MicroPearls LM: 75\% lysine and 25\% methionine.

** Information obtained through analyses conducted at the animal nutrition laboratory of UFU and the Federal Institute of Uberaba. DM - dry matter; CP - crude protein; NDF - neutral detergent fiber; NDA - acid detergent fiber; EE - ethereal extract. 
Food was offered daily at $08 \mathrm{~h} 00$ and $16 \mathrm{~h} 00$, with $50 \%$ of the total daily ration provided at each meal. Amino acids were supplied integrally in the morning meal and were manually mixed into the food directly in the trough. The amounts of amino acids were weighed on a Shimadzu ${ }^{\circledR}$ UX420H digital scale (precision: 0.0001g). Each day, the quantities offered and any leftovers were weighed with a Filizola ${ }^{\circledR}$ CS-15 electronic scale (precision: $0.005 \mathrm{~g}$ ) to monitor feed consumption. The rations were provided such that more than $10 \%$ of the total of the quantities offered was provided. Leftovers were collected and stored in properly identified plastic bags and kept in a freezer at $-10{ }^{\circ} \mathrm{C}$. After the collection period, samples were individually homogenized and a representative aliquot was separated for bromatological analyses.

Water consumption was calculated based on the difference between the amount offered $\left(6 \mathrm{~L} \mathrm{animal}^{-1}\right)$ and the amount leftover. Total water consumption was calculated by adding the water from the bucket to the water contained in the diet ingested. Both calculations were done by discounting the amount of water evaporated, which was obtained by placing $6 \mathrm{~L}$ of water in a bucket and subtracting the leftovers the next day. The bucket used for evaporation was the same as those used for drinking by the animals and allocated at the same height.

Below the metabolic cages, an artifact was maintained that allowed the separation of the feces, making possible the evaluation of the digestibility. To collect all feces, cages were cleaned daily in the morning with a spatula and broom. Feces were weighed, homogenized, and a representative aliquot of the sample was collected once daily in the morning. The aliquots were packed in plastic bags, identified and kept in a freezer at $-100{ }^{\circ} \mathrm{C}$. To evaluate the fecal score, we used the scale proposed by Gomes (2008): 1- dry and deflated stools, 2normal stools, 3- slightly soft stools, 4- soft stools, lacking shape and sticking together (i.e. a bunch of grapes), 5- soft and unformed stools, 6- diarrheic stools.
To prevent nitrogen loss by volatilization, we added $100 \mathrm{~mL}$ of $2 \mathrm{~N}$ sulfuric acid to the buckets used for urine collection. Urine volume was measured daily in the morning with a plastic graduated test tube. Urine density was evaluated at the same time with a Megabrix ${ }^{\circledR}$ manual refractometer. Representative aliquots of urine were collected once daily in the morning, and were subsequently packaged in properly identified bottles and stored in a freezer at $-10^{\circ} \mathrm{C}$. Before storage, samples were filtered on a paper filter (that used to strain coffee) and possible contaminations were removed. At the end of the collection period, samples corresponding to each animal were thawed, homogenized and filtered again using a paper filter, and a $20 \%$ aliquot was withdrawn for later laboratory analysis.

The first round of drying of leftovers and feces samples occurred in a forced air circulation oven at $55^{\circ} \mathrm{C}$ for $72 \mathrm{~h}$, until a constant weight was obtained. Samples were then milled with Willey-type knives equipped with 1-mm diameter sieves. Afterwards, these samples underwent a second round of drying at $105{ }^{\circ} \mathrm{C}$ for $24 \mathrm{~h}$. After this time, it was then possible to calculate the final dry matter of the same and nutrient content, the apparent digestibility of nutrients and dry matter by the following formulas (MAYNARD et al., 1984):

$$
\mathrm{CN}=(\text { Cons } \times \% \text { Cons })-(\text { Under } \times \% \text { Under })
$$

Where: $\mathrm{CN}=$ nutrient consumption $(\mathrm{kg})$; Cons = amount of food consumed $(\mathrm{kg}) ; \%$ Cons = nutrient content in feed provided (\%); Under $=$ amount of leftover withdrawal $(\mathrm{kg}) ; \%$ Under $=$ nutrient content in leftovers (\%).

$$
\mathrm{AD}=\frac{\mathrm{NC}-(\mathrm{CF} \times \% \mathrm{CF})}{\mathrm{NC} \times 100}
$$

Where: $\mathrm{AD}=$ apparent digestibility $(\%) ; \mathrm{CF}=$ amount of feces collected $(\mathrm{kg}) ; \% \mathrm{CF}=$ nutrient content in feces $(\%) ; \mathrm{CN}=$ nutrient consumption (kg). 
Crude protein (CP) content was determined according to the methodology described by Silva and Queiroz (2002), and neutral detergent fiber (NDF) and acid detergent fiber (ADF) were calculated according to the methodology described by Van Soest (1994). Crude protein intake (CPI), neutral detergent fiber intake (NDFI), acid detergent fiber intake (ADFI) and dry matter intake (DMI) were calculated through the difference between the amount supplied and the amount left over.

The urine $\mathrm{N}$ content was calculated using the Kjeldahl method (SILVA; QUEIROZ, 2002), with the following adaptations:

- $1 \mathrm{~mL}$ urine sample, $5 \mathrm{~mL}$ sulfuric acid (H2SO4) and catalytic mixture were added to a test tube;

- Samples were digested at $50{ }^{\circ} \mathrm{C}$ and the temperature was gradually increased until approximately $400{ }^{\circ} \mathrm{C}$, when the sample changed color to show a greenish color, indicating its complete digestion;

Samples were subsequently distilled, and distilled water was added to the digested sample. In the distillation apparatus, we added $25 \mathrm{~mL} \mathrm{50 \%}$ sodium hydroxide $(\mathrm{NaOH})$ and $20 \mathrm{~mL}$ boric acid (H3BO3) in an Erlenmeyer flask. The volume of the distilled sample was $100 \mathrm{~mL}$;

- After distillation, the sample was titrated using $0.1 \mathrm{~N}$ hydrochloric acid $(\mathrm{HCl})$, with acid added until the sample changed color.

The amount of acid used in the titration was used to calculate the $\mathrm{N}$ content of the sample using the following formula:

$$
\% \mathrm{~N}=\frac{\mathrm{V} \times \mathrm{CF} \times \mathrm{N} \times 0.014}{\mathrm{~W}} \times 100
$$

Where: $\mathrm{V}=$ volume of $0.1 \mathrm{~N} \mathrm{HCl}$ used in the titration; $\mathrm{CF}=$ correction factor of $0.1 \mathrm{~N} \mathrm{HCl} ; \mathrm{N}=$ normality of the acid used in the titration; $0.014=$ milliequivalent-gram of nitrogen; $\mathrm{P}=$ weight of the sample (g).
The balance of $\mathrm{N}$, or nitrogen retained was calculated using the formula proposed by Zeoula et al. (2006):

$\mathrm{BN}=[\mathrm{N}$ provided $(\mathrm{g})-\mathrm{N}$ left over $(\mathrm{g})]-[\mathrm{N}$ feces $(\mathrm{g})+\mathrm{N}$ urine $(\mathrm{g})]$

Consequently, the consumption of $\mathrm{N}(\mathrm{CN})$ and the relationship between ingested $\mathrm{N}$ and $\mathrm{N}$ withheld (NING NRET ${ }^{-1}$ ) were calculated using the following formulas:

$$
\mathrm{CN}=\mathrm{N} \text { provided }(\mathrm{g})-\mathrm{N} \text { leftovers }(\mathrm{g})
$$

$$
\frac{\mathrm{BN}}{\mathrm{CN}}
$$

For the measurement of ingestive behavior, the animals were observed by trained personnel, in a relay system, arranged so as not to disturb the animals. Observations occurred for $24 \mathrm{~h}$, and always occurred on the last day of data collection. During the night, the environment was artificially lit, and the lights were kept on for five days prior to observation to allow the animals to adapt. Feed and water intake (INT), rumination (RUM) and resting (REST) behaviors were noted every five minutes, according to the methodology proposed by Fischer et al. (1998). Activity was calculated in minutes per day, under the assumption that within five minutes of each observation, the animal remained in the same activity. The total time spent chewing (CHEW) was determined by adding the time spent in ingestion (ING) and rumination (RUM).

The general design was a $5 \times 5$ Latin square (animals $\mathrm{x}$ periods). The means of all data were analyzed using a $5 \%$ probability regression study, with the exception of the fecal score, which was compared using non-parametric statistics (KRUSKAL; WALLIS, 1952). All variables were tested for normality and homogeneity. 


\section{Results and Discussion}

Dry matter intake, in relation to metabolic weight and body weight, showed a positive linear response (Table 2); that is, the higher the inclusion of protected amino acids in the diet, the higher the consumption, with a $16.94 \%$ difference between the lowest and highest consumption levels $(0 \mathrm{~g}$ and $32 \mathrm{~g}$ ). According to the NRC (2007), it is recommended that lambs in this category consume $1.39 \mathrm{~kg}$ DMI day ${ }^{-1}$. Thus, animals receiving $32 \mathrm{~g}$ of protected amino acids consumed $3.59 \%$ more than the recommended level, while those that did not receive the amino acids consumed $13.95 \%$ below the recommended level.

Table 2. Dry matter intake (DMI), dry matter intake in relation to metabolic weight (DMI MW) and body weight (DMI BW) and dry matter digestibility (DMD) of lambs receiving rations with different levels of protected amino acids.

\begin{tabular}{ccccc}
\hline Amino acid level * & DMI $^{1}\left(\mathrm{~kg} \mathrm{day}^{-1}\right)$ & $\mathrm{DMI} \mathrm{MW}^{2}\left(\mathrm{~kg} \mathrm{day}^{-1}\right)$ & $\mathrm{DMI} \mathrm{BW}^{3}(\%)$ & DMD (\%) \\
\hline $0 \mathrm{~g}$ & 1.196 & 60.23 & 2.22 & 79.42 \\
$8 \mathrm{~g}$ & 1.328 & 67.17 & 2.48 & 82.26 \\
$16 \mathrm{~g}$ & 1.324 & 67.35 & 2.49 & 80.78 \\
$24 \mathrm{~g}$ & 1.294 & 65.54 & 2.43 & 78.96 \\
$32 \mathrm{~g}$ & 1.440 & 73.96 & 2.74 & 81.77 \\
\hline Mean & 1.31 & 66.78 & 2.47 & 80.64 \\
$\mathrm{CV}$ & 8.07 & 8.28 & 8.47 & 3.02 \\
\hline
\end{tabular}

*MicroPearls LM: $75 \%$ lysine and $25 \%$ methionine.

$\mathrm{CV}$ - coefficient of variation; ${ }^{1} \hat{\mathrm{Y}}=1.225600+0.005675 \mathrm{x}, \mathrm{R}^{2}=67.65 \% ;{ }^{2} \hat{\mathrm{Y}}=61.74400+0.315925 \mathrm{x}, \mathrm{R}^{2}=68.99 \% ;{ }^{3} \hat{\mathrm{Y}}=2.28280$ $+0.01210 \mathrm{x}, \mathrm{R}^{2}=69.98 \%$.

The higher amount of protected amino acids in the diet may have provided better compliance with the metabolizable protein requirements of lambs, whereas the ingredients used in the concentrate (soybean meal and maize, silage and urea; Table 1) served as a source of rumen degradable protein RDP); this increased the amount of protein synthesized by ruminal microorganisms, since the synthesis of microbial protein is dependent on the concentration and quality of energy sources and the dietary nitrogen in the rumen (RIBEIRO et al., 2001). This balance between protein sources may have led to increased food consumption. The energy supply that reaches the intestine of the animal comes mainly from the digestion of protein, carbohydrates and long chain fatty acids (BERCHIELLI et al., 2006). The provided ration was highly palatable, which also benefited consumption.

According to Alves (2004), when the metabolizable protein is of high quality (i.e. rich and with the appropriate essential amino acid profile), the crude protein content of the feed can be reduced, the efficiency of the use of metabolizable protein is optimized, excretion of urea and other nitrogen compounds is reduced (lower energy expenditure) and the animal generally performs better. Antongiovanni et al. (2002) did not observe improvements in dry matter intake with the addition of protected methionine and lysine in feed for two-month-old lambs. Prado (2013) evaluated the inclusion of lysine (48.5\% L-lysine hydrochloride) and methionine (55.3\% methionine) separately in rations for uncastrated, Dorper x Santa Inês mestizos male lambs weighing approximately 20.57 $\mathrm{kg}$ (live weight); Prado observed a lower average daily intake of rations containing protected amino acids, compared to the control diet, with values of $1.295,1.228$ and $1.153 \mathrm{~kg} \mathrm{day}^{-1}$, respectively for the control, methionine and lysine treatments. 
In rations with digestibility values lower than $66 \%$, food intake is determined by physical factors; that is, they are related to the physical distention of the rumen-reticulum. However, in diets with digestibility values greater than $66 \%$, physiological factors control food intake; that is, the energy or nutritional balance of the diet (MERTENS, 1994; CONRAD et al., 1964). In the present study, the mean value for dry matter digestibility (DMD) was 80.64, and this did not differ between treatments. The high digestibility value observed may be a result of the feed having a $70 \%$ concentrate composition, providing highly fermentable grains in the rumen.

According to the NRC (1985), microbial growth is dependent on the ratio of particle size, volume and feed rate per rumen; an increase in the rate of passage reduces the average age of the microbial population due to the removal of mature organisms, and consequently reduces the energy demand of the microbiota. Thus, there is greater efficiency in the use of system energy for microbial growth (POLAN, 1988). In this study, digestibility remained high in all treatments, even with the observed change in DMI (Table 2), indicating that the highenergy intake of the diet promoted an increase in microbial growth and passage rate. In addition, the concentrate contained urea (Table 1). This nitrogen source is readily degraded in the rumen, and used in the formation of microbial protein. Han et al. (1996) evaluated diets with and without the inclusion of protected lysine and methionine in sheep with a mean weight of $50 \mathrm{~kg}$; they observed a higher DMD with the inclusion of amino acids, with an increase from $69.4 \pm 1.75 \%$ to $72.6 \pm 2.20 \%$. Consumption of dry matter in relation to body weight (DMI BW$\left.{ }^{1}\right)$ was lower than the $2.78 \%$ level recommended by the NRC (2007). This $11 \%$ reduction in DMI $\mathrm{BW}^{-1}$ in the present study may be due to genetic differences between the animals used.

Crude protein (CP) and neutral detergent fiber (NDF) intake followed a linear positive response with the increase in amino acids (Table 3). The NRC (2007) recommends a crude protein intake (CPI) of
$0.168 \mathrm{~kg} \mathrm{day}^{-1}$ for growing lambs. In the present study, the lowest consumption of crude protein occurred in the treatment without the addition of protected amino acids, but this still remained 59\% higher than the recommended level, while animals receiving $32 \mathrm{~g}$ of amino acids consumed $97 \%$ more than the recommended level. This increase may be related to the fact that the ration was formulated by international committees that may have overestimated the consumption of the animals.

Geron et al. (2013) worked with different amounts of concentrate, based on milled grain and soybean meal, at $20 \%, 40 \%, 60 \%$ and $80 \%$ in the diet of lambs with an average weight of 19.3 $\pm 2.1 \mathrm{~kg}$. They noted a mean CP of $12.80 \%$ and a maximum CPI of $77.37 \mathrm{~g} \mathrm{day}^{-1}$. This shows that the CPI in the present study is in fact related to the high crude protein content of the diet (Table 1), with higher CPI as the amounts of protected amino acids increased. Crude protein digestibility (CPD) was not influenced $(\mathrm{P}>0.05)$ by the treatments, with a mean value of $86.63 \%$ (Table 3 ). In addition to the CP content of the concentrate, another factor that may have contributed to the high CPD is the presence of urea in the concentrate and the source of RDP (soybean meal). The composition of the concentrate may have increased the synthesis of microbial protein in the rumen. This probably also improved the amino acid profile that reached the small intestine, which, together with the protected amino acids, formed the metabolizable protein. This improved contribution of amino acids may have contributed to the high observed values of CPD. According to Zeoula et al. (2006), when the availability of RDP is increased in the presence of a starch source with high ruminal degradability, such as maize, the available energy is sufficient to provide synchronization with the released $\mathrm{N}$, causing an increase in digestibility. Geron et al. (2013) found higher CPD values with $40 \%$ concentrate in the diet, with values of $58.96 \%$. Moreno et al. (2010) fed lambs a diet containing concentrate with $19 \%$ crude protein based on soybean meal and milled corn and noted a mean CPD of $78.22 \%$. 
Table 3. Crude protein (CPI), neutral detergent fiber (NDFI) and acid detergent fiber (ADFI) intake, and crude protein (CPD) and neutral detergent fiber digestibility (NDFD) in lambs receiving different levels of protected amino acids.

\begin{tabular}{cccccc}
\hline Amino acid level & $\mathrm{CPI}^{1}\left(\mathrm{~kg} \mathrm{day}^{-1}\right)$ & $\mathrm{CPD}(\%)$ & $\mathrm{NDFI}^{2}\left(\mathrm{~kg} \mathrm{day}^{-1}\right)$ & $\mathrm{ADFI}\left(\mathrm{kg} \mathrm{day}^{-1}\right)$ & $\mathrm{NDFD}(\%)$ \\
\hline $0 \mathrm{~g}$ & 0.268 & 86.51 & 0.382 & 0.149 & 67.77 \\
$8 \mathrm{~g}$ & 0.297 & 86.97 & 0.412 & 0.161 & 71.21 \\
$16 \mathrm{~g}$ & 0.296 & 86.27 & 0.401 & 0.151 & 67.43 \\
$24 \mathrm{~g}$ & 0.293 & 86.31 & 0.386 & 0.152 & 67.72 \\
$32 \mathrm{~g}$ & 0.332 & 87.11 & 0.415 & 0.168 & 69.46 \\
Mean & 0.297 & 86.63 & 0.406 & 0.156 & 68.72 \\
$\mathrm{CV}$ & 8.30 & 2.64 & 9.28 & 14.00 & 7.90 \\
\hline
\end{tabular}

* MicroPearls LM: $75 \%$ lysine and 25\% methionine.

$\mathrm{CV}$ - coefficient of variation; ${ }^{1} \hat{\mathrm{Y}}=0.272820+0.001557 \mathrm{x}, \mathrm{R}^{2}=74.26 \% ;{ }^{2} \hat{\mathrm{Y}}=0.384568+0.001400 \mathrm{x}, \mathrm{R}^{2}=41.14 \%$.

The consumption of neutral detergent fiber (NDFI) followed a positive, linear response to the inclusion of amino acids (Table 3 ). This variable is directly related to the ingestion of bulk, the increase in NDFI is related to an increase in DMI (Table 2), since the V: C ratio was the same in all treatments. Geron et al. (2013) found NDFI values of 268.44 and $158.74 \mathrm{~g}$ day $^{-1}$ when working with $20 \%$ and $60 \%$ concentrate in the diet of lambs, respectively. Macedo Junior et al. (2006) found a NDFI of 604.47 $\mathrm{g} \mathrm{day}^{-1}$ in Santa Inês sheep fed a diet containing $34.69 \%$ NDF. There were no effects of the amino acid contents on NDF digestibility (Table 3). Geron et al. (2013) and Moreno et al. (2010) also did not observe any difference $(\mathrm{P}>0.05)$ in NDFD, observing values of 48.07 and $44.55 \%$, respectively. Sun et al. (2007) observed an increase from 49.3 to $50.7 \%$ of NDFD in goats, compared to a control ration and a ration including protected lysine and methionine, respectively.

Nitrogen balance is indicative of protein metabolism and is an important parameter in the evaluation of food and whether the animal is in equilibrium with respect to its nitrogen compounds (GUIMARÃES JÚNIOR et al., 2007). Ingested N values followed a positive linear response (Table 4). For basal maintenance of microbial activity in the rumen, $1 \% \mathrm{~N} \mathrm{DMI}^{-1}$ is recommended. In the present study, the animals ingested on average $3 \% \mathrm{~N} \mathrm{DMI}^{-1}$. The nitrogen intake in the present study is related to the increase in DMI, and consequently CPI (Table 2 and 3), and to the increase in supplemental protected amino acids in the concentrate.

Table 4. Ingested nitrogen ( $\mathrm{N}$ ingested), fecal nitrogen $(\mathrm{N}$ fecal), urinary nitrogen ( $\mathrm{N}$ urinary), nitrogen balance (NB) and nitrogen retained and ingested $\left(\mathrm{NR} \mathrm{IN}^{-1}\right)$ in lambs receiving different levels of protected amino acids.

\begin{tabular}{cccccc}
\hline Amino acid level * & $\mathrm{N}_{\text {ingested }}\left(\mathrm{g} \mathrm{day}^{-1}\right)$ & $\mathrm{N}$ fecal $\left(\mathrm{g} \mathrm{day}^{-1}\right)$ & $\mathrm{N}$ urinary $\left(\mathrm{g} \mathrm{day}^{-1}\right)$ & $\mathrm{NB}^{2}\left(\mathrm{~g} \mathrm{day}^{-1}\right)$ & $\mathrm{NR} \mathrm{IN}^{-1}$ \\
\hline $0 \mathrm{~g}$ & 33.26 & 6.01 & 8.87 & 17.68 & 0.53 \\
$8 \mathrm{~g}$ & 41.70 & 6.26 & 8.87 & 25.14 & 0.62 \\
$16 \mathrm{~g}$ & 42.32 & 6.29 & 8.48 & 27.23 & 0.67 \\
$24 \mathrm{~g}$ & 41.13 & 6.34 & 9.87 & 23.41 & 0.61 \\
$32 \mathrm{~g}$ & 47.48 & 6.66 & 8.33 & 30.52 & 0.67 \\
Mean & 41.18 & 6.31 & 8.89 & 24.79 & 0.62 \\
$\mathrm{CV}$ & 11.19 & 16.65 & 30.09 & 26.87 & 16.47 \\
\hline
\end{tabular}

* MicroPearls LM: $75 \%$ lysine and 25\% methionine.

$\mathrm{CV}$ - coefficient of variation; ${ }^{1} \hat{\mathrm{Y}}=135.60440+0.348475 \mathrm{x}, \mathrm{R}^{2}=74.73 \% ;{ }^{2} \hat{\mathrm{Y}}=20.00840+0.299325 \mathrm{x}, \mathrm{R}^{2}=62.74 \%$. 
As there was no difference ( $\mathrm{P}>0.05)$ for $\mathrm{DMD}$, the increase in $\mathrm{N}$ intake also had no influence on fecal and urinary $\mathrm{N}$ excretion (Table 4). Fecal $\mathrm{N}$ losses corresponded to $15.32 \%$ of the total ingested $\mathrm{N}$. The high values found for DMD and CPD (Table 3) indicated better use of ingested N by reducing excretion via feces. Nitrogen losses via urine corresponded to $21.58 \%$ of the total $\mathrm{N}$ ingested. This indicates that the increase in CPI and ingested $\mathrm{N}$ from concentrate and silage resulted in excess nitrogen in the rumen, causing the animal to concentrate its elimination through urine to avoid possible ammonia intoxication. This mechanism results in an increased energy expenditure by the liver, given that the synthesis of urea from ammonia is an energy-intensive process; in sheep, this is estimated to be $88.4 \mathrm{kcal} \mathrm{mol}^{-1}$ (MARTIN; BLAXTER, 1965). Moreno et al. (2010) found losses of 40.74 and $22.20 \%$ for fecal and urinary $\mathrm{N}$, respectively. Han et al. (1996) observed a decrease in the excretion of $\mathrm{N}$ with the inclusion of lysine and methionine in the diet of sheep; they noted values of $12.1 \pm 1.10$ and $9.6 \pm 0.05 \mathrm{~g} \mathrm{day}^{-1}$ for fecal $\mathrm{N}$ and $12.9 \pm 0.93$ and $7.8 \pm 0.47 \mathrm{~g} \mathrm{day}^{-1}$ for urinary $\mathrm{N}$.

Nitrogen balance (NB) followed a positive linear response to the inclusion of amino acids in the diet (Table 4). The fact that NB was positive indicates that the animals did not need to dislocate body protein reserves to meet their nutritional requirements. According to Zeoula et al. (2006), higher NB values in diets with high concentrate content may be due to higher CP intake and digestibility. In fact, in the present study, we observed that the animals that received higher amounts of protected lysine and methionine showed higher DMI, CPI and NB (Tables 2, 3 and 4).

Water consumption did not differ between treatments $(\mathrm{P}>0.05$; Table 5). According to the NRC (2007), there is a correlation between dry matter intake and water consumption, with $1 \mathrm{~kg}$ DM corresponding to $2.78 \mathrm{~L}$ of water. The animals in this experiment ingested an average of $1.72 \mathrm{~L}$ of extra water per $\mathrm{kg}$ of DM ingested. Forbes (1968) proposed an equation that allows for the calculation of daily water intake requirements based on DMI, namely: $\mathrm{CH}_{2} \mathrm{O}=3.86$ x DMI - 0.99. Using the mean value of DMI obtained in the present study, the recommended water intake is $4.06 \mathrm{~L} \mathrm{day}^{-1}$. Thus, water consumption was $58 \%$ higher than the recommendation. This increase may have been alternatively created to help eliminate excess CP from the diet as a way to avoid ammonia poisoning. Another explanation is related to the time of the year in which the experiment was conducted: during a hot season, inducing the consumption of water.

Table 5. Water consumption $\left(\mathrm{CH}_{2} \mathrm{O}\right)$, total water consumption (total $\mathrm{CH}_{2} \mathrm{O}$ ), water consumption in relation to dry matter consumption $\left(\mathrm{CH}_{2} \mathrm{O} \mathrm{DMI}^{-1}\right)$, volume of urine (VU), urine density (UD), weight of feces in natural matter (WFNM) and dry matter (WFDM), fecal dry matter (FDM) and fecal score (FE) of ewes receiving different levels of protected amino acids.

\begin{tabular}{|c|c|c|c|c|c|}
\hline Amino acid level * & $\mathrm{CH}_{2} \mathrm{O}(\mathrm{L})$ & $\mathrm{CH}_{2} \mathrm{O}$ total $(\mathrm{L})$ & $\mathrm{CH}_{2} \mathrm{O} \mathrm{DMI}^{-1}\left(\mathrm{~L} \mathrm{~kg}^{-1}\right)$ & $\mathrm{VU}\left(\mathrm{mg} \mathrm{dL}^{-1}\right)$ & $\mathrm{UD}\left(\mathrm{mg} \mathrm{dL}^{-1}\right)$ \\
\hline $0 \mathrm{~g}$ & 5.10 & 5.63 & 4.33 & 2.68 & 1.0176 \\
\hline $8 \mathrm{~g}$ & 5.67 & 6.30 & 4.24 & 2.71 & 1.0152 \\
\hline $16 \mathrm{~g}$ & 6.57 & 7.19 & 5.22 & 3.14 & 1.0146 \\
\hline $24 \mathrm{~g}$ & 5.71 & 6.33 & 4.40 & 3.00 & 1.0128 \\
\hline $32 \mathrm{~g}$ & 6.15 & 6.81 & 4.31 & 3.00 & 1.0158 \\
\hline Mean & 5.84 & 6.45 & 4.50 & 2.91 & 1.0152 \\
\hline $\mathrm{CV}$ & 18.66 & 16.90 & 23.36 & 26.90 & 0.40 \\
\hline
\end{tabular}


continuation

\begin{tabular}{ccccc}
\hline Amino acid level * & WFNM $(\mathrm{g})$ & WFDM $(\mathrm{g})$ & FDM $(\%)$ & FE* \\
\hline $0 \mathrm{~g}$ & 0.58 & 0.20 & 35.43 & $2.40 \mathrm{~B}$ \\
$8 \mathrm{~g}$ & 0.66 & 0.21 & 32.45 & $3.12 \mathrm{~A}$ \\
$16 \mathrm{~g}$ & 0.58 & 0.22 & 37.51 & $2.36 \mathrm{~B}$ \\
$24 \mathrm{~g}$ & 0.63 & 0.22 & 36.28 & $2.48 \mathrm{~B}$ \\
$32 \mathrm{~g}$ & 0.59 & 0.22 & 39.27 & $2.20 \mathrm{~B}$ \\
\hline Mean & 0.61 & 0.21 & 36.19 & 2.51 \\
$\mathrm{CV}$ & 21.66 & 14.89 & 12.05 & - \\
\hline
\end{tabular}

*MicroPearls LM: 75\% lysine and 25\% methionine.

$\mathrm{CV}$ - coefficient of variation.

* Assessed using non-parametric statistics.

There was no difference $(\mathrm{P}>0.05)$ in the values for urine volume and density (Table 5). Hendrix (2005) suggests a variation of 1.020 to $1.040 \mathrm{mg}$ $\mathrm{dL}^{-1}$ for urine density in sheep. Here, urine density mean values were $1.015 \mathrm{mg} \mathrm{dL}^{-1}$, which is below the recommended value. However, according to Carlson (1993), it is normal to find urine density below $1.010 \mathrm{mg} \mathrm{dL}^{-1}$ in young animals due to the high fluid intake, as was observed in the present study. The higher the intake of food, protein and non-protein nitrogen, the greater the urine output, as a consequence of increased water intake from both the food and water itself. Therefore, higher intakes of DM and $\mathrm{CP}$ resulted in an increase in water intake and urine volume, which is a way to eliminate excess nutrients from the diet. In cases of water deficit, urine volume is lower, as there is a decrease in blood supply to the kidneys and a greater reabsorption of water in the renal tubules (OSBALDISTON; MOORE, 1971).

No statistical differences were observed for feces weight in natural matter, dry matter and fecal dry matter (Table 5). Stool weight may be related to diet composition, rumen feed rate and digestibility. As the rations contained the same V: C ratio, it had no effect on feces weight and digestibility (Table $2)$. The fecal score was higher $(\mathrm{P}<0.05)$ for the 8 $\mathrm{g}$ treatment. According to Gomes (2008), the ideal score is 2.0, which characterizes feces as normal and is indicative of a normal health condition of the animals. The $8 \mathrm{~g}$ treatment had a fecal score of 3.12, which is characterized as slightly softened stools, corresponding to $38 \%$ above the recommended score. Very high scores are indicative of diets with high passage rates and some disturbance. However, this was not the case in our study, as no difference was observed in DMD between treatments (Table 2).

The different levels of protected amino acids did not influence $(\mathrm{P}>0.05)$ the analyzed variables for the ingestive behavior of lambs over the 24-h period (Table 6). This may be related to the diets not presenting variations in their fiber contents. Van Soest (1994) established that rumination activity in adult animals should occupy around 8 $\mathrm{h}$ per day, with variations between 4 and $9 \mathrm{~h}$. This difference is related to dietary components and is proportional to the cell wall content of bulky foods. In the present study, the animals spent on average of $4 \mathrm{~h} 13 \mathrm{~min}$ in rumination activities, which is the minimum value proposed by Van Soest (1994). This result can be related to the high fiber quality in the rations. In addition, the fact that the animals remained in metabolic cages favored the animals' easy access to food, thus reducing the time required for ingestion and rumination and increasing the time spent resting. Another important factor is that $70 \%$ of the feed was composed of concentrate, which is more easily ingested compared to corn silage, and causes little stimulation of rumination. Rations 
with this characteristic are rapidly digested in the rumen, since they have high amounts of non-fibrous carbohydrates (MERTENS, 1987), explaining the low noted values for rumination time.

Table 6. Effect of the use of different levels of protected amino acids on the ingestive behavior of lambs over 24 hours.

\begin{tabular}{ccccccccc}
\hline $\begin{array}{c}\text { Amino } \\
\text { acid level* }^{*}\end{array}$ & $\begin{array}{c}\text { Int. } \\
\left(\text { min day }^{-1}\right)\end{array}$ & $\begin{array}{c}\text { Rum. } \\
\left(\text { min day }^{-1}\right)\end{array}$ & $\begin{array}{c}\text { Rest. } \\
\left(\text { min day }^{-1}\right)\end{array}$ & $\begin{array}{c}\text { Chew. } \\
\left(\text { min day }^{-1}\right)\end{array}$ & $\begin{array}{c}\text { Int. } \\
(\% \text { of day })\end{array}$ & $\begin{array}{c}\text { Rum. } \\
(\% \text { of day })\end{array}$ & $\begin{array}{c}\text { Rest. } \\
(\% \text { of day })\end{array}$ & $\begin{array}{c}\text { Chew. } \\
(\% \text { of day })\end{array}$ \\
\hline $0 \mathrm{~g}$ & 183.00 & 241.00 & 1016.00 & 424.00 & 12.71 & 16.73 & 70.55 & 29.44 \\
$8 \mathrm{~g}$ & 175.00 & 250.00 & 1015.00 & 425.00 & 12.15 & 17.36 & 70.48 & 29.51 \\
$16 \mathrm{~g}$ & 172.00 & 281.00 & 987.00 & 453.00 & 11.94 & 19.51 & 68.54 & 31.45 \\
$24 \mathrm{~g}$ & 197.00 & 229.00 & 1019.00 & 421.00 & 13.68 & 15.90 & 70.76 & 29.23 \\
$32 \mathrm{~g}$ & 193.00 & 268.00 & 979.00 & 461.00 & 13.40 & 18.61 & 67.98 & 32.01 \\
Mean & 184.00 & 253.80 & 1003.20 & 436.80 & 12.77 & 17.62 & 69.66 & 30.33 \\
$\mathrm{CV}$ & 18.13 & 21.06 & 6.15 & 14.13 & 18.13 & 21.06 & 6.15 & 14.13 \\
\hline
\end{tabular}

*MicroPearls LM: $75 \%$ lysine and 25\% methionine.

Int. - Intake; Rum. - Rumination; Rest. - Resting; Chew. - chewing.

The time animals spent resting corresponded to $69.66 \%$ of the total time budget. Cirne et al. (2014) evaluated different crude protein levels in the diet of sheep and observed that the animals spent an average of $78 \%$ of their time resting. The animals were engaged in chewing activity for an average of $7 \mathrm{~h}$ of the evaluation period. The ruminant chewing process is fundamental to the maintenance of ruminal health, given that saliva production occurs during chewing, and this saliva is responsible for buffering to avoid possible problems, such as acidosis (VAN SOEST, 1994). Chewing activity includes the sum of the intake and rumination values. There was no difference $(\mathrm{P}>0.05)$ in the ingestion, rumination and chewing efficiencies (Table 6); these results demonstrate the animal's ability to ingest, ruminate and chew food and are expressed in $\mathrm{g}^{-1}$ minutes. Thus, the level of amino acids included in the feed did not alter the efficiency of the parameters of ingestive behavior of the animals.

\section{Conclusions}

The use of up to $32 \mathrm{~g}$ of amino acids protected from ruminal degradation is indicated for low performing $1 / 2$ Dorper $x 1 / 2$ Santa Inês lambs as it provides an increase in dry matter and nutrient intakes, without reducing their digestibilities.

\section{References}

ALVES, D. Nutrição aminoacídica de bovinos. Revista Brasileira de Agrociência, Pelotas, v. 10, n. 3, p. 265271, 2004.

ANTONGIOVANNI, M.; ACCIAIOLI, A.; FRANCI, O.; PONZETTA, M. P.; PUGLIESE, C.; BUCCIONI, A.; BADII, M. Field bean (Vicia faba var. minor) as a protein feed for growing lambs with and without protected lysine and methionine supplementation. Italian Journal of Animal Science, Pavia, v. 1, n. 3, p. 229-238, 2002.

ARRIOLA APELO, S. I.; SINGER, L. M.; RAY, W. K.; HELM, R. F.; LIN, X. Y.; McGILLIARD, M. L.; St-PIERRE, N. R.; HANIGAN, M. D. Casein synthesis is independently and additively related to individual essential amino acid supply. Journal of Dairy Science, Champaign, v. 97, n. 5, p. 2998-3005, 2014.

BERCHIELLI, T. T.; PIRES, A. V.; OLIVEIRA, S. G. Nutrição de ruminantes. In: RESENDE, K. T.; TEIXEIRA, I. A. M. A.; FERNANDES, M. H. M. R. (Ed.). Metabolismo de energia. Jaboticabal: FUNEP, 2006. p. 311-332.

CARLSON, G. P. Testes bioquímicos. In: SMITH, B. P. Tratado de medicina interna de grandes animais. São Paulo: Manole, 1993. p. 395-423. 
CIRNE, L. G. A.; OLIVEIRA, G. J. C.; BAGALDO, A. R.; LEITE, M. C. P.; ROCHA, N. B.; MACEDO JUNIOR, C. M.; OLIVEIRA, P. A. Comportamento ingestivo de cordeiros em confinamento, alimentados com dieta exclusiva de concentrado com diferentes porcentagens de proteína. Arquivo Brasileiro de Medicina Veterinária e Zootecnia, Belo Horizonte, v. 66, n. 1, p. 229-234, 2014.

CONRAD, H. R.; PRATT, A. D.; HIBBS, J. W. Regulation of feed intake in dairy cows. Change in importance of physical and physiological factors with increasing digestibility. Journal of Dairy Science, Champaign, v. 47, n. 1, p. 54-62, 1964.

FISCHER, V.; DESWYSEN, A. G.; DÈSPRES, L.; DUTILLEUL, P.; LOBATO, J. F. P. Padrões nectemerais do comportamento ingestivo de ovinos. Revista Brasileira de Zootecnia, Viçosa, MG, v. 27, n. 2, p. 362-369, 1998.

FORBES, J. M. Water intake of ewes. British Journal of Nutrition, London, v. 22, n. 1, p. 33-43, 1968.

GERON, L. J. V.; MEXIA, A. A.; CRISTO, T. L.; GARCIA, J.; CABRAL, L. S.; MACHADO, R. J. T.; MARTINS, O. S.; ZEOULA, L. M. Consumo, digestibilidade dos nutrientes e características ruminais de cordeiros alimentados com níveis crescentes de concentrado em ambiente tropical no Vale do Alto Guaporé - MT. Semina: Ciências Agrárias, Londrina, v. 34, n. 5, p. 2497-2510, 2013.

GOMES, S. P. Tamanho de partícula do volumoso e frequência de alimentação sobre aspectos nutricionais $e$ do metabolismo energético em ovinos. 2008. Tese (Doutorado em Zootecnia) - Escola de Veterinária, Universidade Federal de Minas Gerais, Belo Horizonte.

GUIMARÃES JÚNIOR, R.; GONÇALVES, L. C.; PEREIRA, L. G. R.; PIRES, D. A. de A.; RODRIGUES, J. A. S.; MIRANDA, K. L.; ARAÚJO, V. L. Balanço de nitrogênio em ovinos alimentados com silagens de três genótipos de milheto Pennisetum glaucum (L.) R.Br. In: REUNIÃO ANUAL DA SOCIEDADE BRASILEIRA DE ZOOTECNIA, 44., 2007, Jaboticabal. Anais... Jaboticabal: SBZ, 2007. p. 1-3.

HAN, I. K.; HA, J. K.; LEE, S. S.; KO, Y. G.; LEE, H. S. Effect of supplementing rúmen-protected lysine and methionine on ruminal 21 characteristics and nutrient digestibility in sheep. Asian-Australasian Journal of Animal Sciences, Gwanak-gu, v. 9, n. 2, p. 223-229, 1996.

HENDRIX, C. M. Procedimentos laboratoriais para técnicos veterinários. 4. ed. São Paulo: Rocca, 2005. 556 p.

KRUSKAL, W. H.; WALLIS, W. A. Use of ranks in one-criterion variance analysis. Journal of the American
Statistical Association, New York, v. 47, n. 11, p. 583$621,1952$.

MACEDO JUNIOR, G. L.; PÉREZ, J. R. O.; ALMEIDA, T. R. V.; PAULA, O. J.; FRANÇA, P. M.; ASSIS, R. M. Influência de diferentes níveis de FDN dietético no consumo e digestibilidade aparente de ovelhas Santa Inês. Ciência e Agrotecnologia, Lavras, v. 30, n. 3, p. 547-553, 2006.

MARTIN, A. K.; BLAXTER, K. L. The energy cost of urea synthesis in sheep. In: BLAXTER, K. L. (Ed.). Energy metabolism. London: Academic Press, 1965. p. 83-91.

MAYNARD, L. A.; LOOSLI, B. S.; HINTZ, H. F.; WARNER, R. G. Nutrição animal. 3. ed. Rio de Janeiro: Freitas Bastos, 1984. 726 p.

MERTENS, D. R. Predicting intake and digestibility using mathematical models of ruminal function. Journal of Animal Science, Champaign, v. 64, n. 5, p. 1548-1558, 1987.

MERTENS, D. R. Regulation of forage intake. In: FAHEY JÚNIOR, G. C. (Ed.). Forage quality, evaluation and utilization. Madison: American Society of Agronomy, 1994. p. 450-493.

MORENO, G. M. B.; SOBRINHO, A. G. S.; LEÃO, A. G.; LOUREIRO, C. M. B.; PEREZ, H. L.; ROSSI, R. C. Desempenho, digestibilidade e balanço de nitrogênio em cordeiros alimentados com silagem de milho ou cana-deaçúcar e dois níveis de concentrado. Revista Brasileira de Zootecnia, Viçosa, MG, v. 39, n. 4, p. 853-860, 2010.

NATIONAL RESEARCH COUNCIL - NRC. Nutrient requirements of small ruminants: sheep, goats, cervids, and new world camelids. Washington: National Academy Press, 2007. 384 p.

NATIONAL RESEARCH COUNCIL - NRC. Ruminant nitrogen usage. Washington: National Academy Press, 1985. 138 p.

OSBALDISTON, G. W.; MOORE, W. E. Renal function test in cattle. Journal of the American Veterinary Medical Association, Schaumburg, v. 159, n. 3, p. 292-301, 1971.

POLAN, C. E. Dietary protein and microbial protein contribution. Journal of Nutrition, Bethesda, v. 18, n. 2, p. 242-248, 1988.

PRADO, T. F. Metionina protegida, lisina protegida, enzima amilolítica e lisofosfolipídeos em dieta de alto concentrado para cordeiros confinados. 2013. Dissertação (Mestrado em Nome do Curso) - Escola de Veterinária e Zootecnia, Universidade Federal de Goiás, Goiânia. 
REID, J. T. Problems of feed evaluation related to feeding dairy cows. Journal of Dairy Science, Champaign, v. 11, n. 7, p. 2122-2133, 1961.

RIBEIRO, K. G.; GARCIA, R.; PEREIRA, O. G.; VALADARES FILHO, S. de C.; CECON, P. R. Eficiência microbiana, fluxo de compostos nitrogenados no abomaso, amônia e $\mathrm{pH}$ ruminais em bovinos recebendo dietas contendo feno de capim-Tifton 85 de diferentes idades de rebrota. Revista Brasileira de Zootecnia, Viçosa, MG, v. 30, n. 2, p. 581-588, 2001.

SANTOS, F. A. P. Metabolismo de proteínas. In: BERCHIELLI, T. T.; VAZ PIRES, A.; OLIVEIRA, S. G. de. Nutrição de ruminantes. Jaboticabal: Funep, 2006. p. 255-284.

SANTOS, F. A. P.; MACEDO, F. L.; CHAGAS, L. J. Aplicação do conceito de proteína ideal para bovinos leiteiros. In: SIMPÓSIO NACIONAL DE BOVINOCULTURA DE LEITE, 3., 2017, Viçosa, MG. Anais... Viçosa, MG: Universidade Federal de Viçosa, 2017. p. 301-334.

SILVA, D. J.; QUEIROZ, A. C. de. Análise de alimentos: métodos químicos e biológicos. Viçosa, MG: UFV, 2002. $235 \mathrm{p}$.
SUN, Z. H.; TAN, Z. L.; LIU, S. M.; TAYO, G. O.; LIN, B.; TENG, B.; TANG, S. X.; WANG, W. J.; LIAO, Y. P.; PAN, Y. F.; WANG, J. R.; ZHAO, X. G.; HU, Y. Effects of dietary methionine and lysine sources on nutrient digestion, nitrogen utilization, and duodenal amino acid flow in growing goats. Journal of Animal Science, Champaign, v. 85, n. 12, p. 3340-3347, 2007.

VALADARES FILHO, S. C. Digestão pós-ruminal de proteína e exigências de aminoácidos para ruminantes In: DIGESTIBILIDADE EM RUMINANTES, 1997, Lavras. Anais... Lavras: Universidade Federal de Lavras, 1997. p. 87-113.

VAN SOEST, P. J. Nutritional ecology of the ruiminant. $2^{\text {th }}$ ed. Ithaca: Cornell University Press, 1994. 476 p.

ZEOULA, L. M.; FERELI, F.; PRADO, I. N.; GERON, L. J. V.; CALDAS NETO, S. F.; PRADO, O. P. P. P.; MAEDA, E. M. Digestibilidade e balanço de nitrogênio de rações com diferentes teores de proteína degradável no rúmen e milho moído como fonte de amido em ovinos. Revista Brasileira de Zootecnia, Viçosa, MG, v. 35, n. 5, p. 2179-2186, 2006. 
